\title{
The Consumer Science of Sharing: A Discussant's Observations
}

\author{
FLOYD RUDMIN
}

\begin{abstract}
This discussant's response to the collected articles on the consumer behavior of sharing draws on a 1983-99 record of research on the psychology of ownership and property. The major recommendations here are: (1) that sharing be defined as the simultaneous or sequential use of an object (e.g., car), a space (e.g., living room), or an intangible (e.g., identity) by more than one individual; (2) that sharing be better described and analyzed by the naive phenomenology methods used by Ichheiser, Heider, and Goffman; (3) that sharing arising from shared ownership be distinguished from sharing arising from an owner's prerogative to share; (4) that ownership be defined as social and legal protection of possessions for future utility in order to allow owners, as Litwinski theorized, to have relaxed expectations, in French, attente dans la détente; (5) that shopping and purchasing are inventory behaviors that are distinct from, and prior to, consumers' use of inventory; (6) that distributed inventory accessed by digitally mediated sharing (e.g., Uber) be examined as alternative inventory behavior; (7) that scholarship on the "sharing economy" better explore and exploit the literatures in the subfields of $(a)$ ownership theory, $(b)$ child development, $(c)$ inventory management, and $(d)$ competition theory.
\end{abstract}

come to the discussant role as a psychologist with a record of scholarship on ownership theory and the psychology of property. My research on these topics falls into three broad domains: (1) interdisciplinary history of ownership (e.g., Rudmin 1985, 1986, 1990a, 1990b, 1991a, 1991c, 1996), (2) cross-cultural correlates of ownership (e.g., Rudmin 1988, 1992a, 1992b, 1995, 1996), and (3) semantics of ownership terms (e.g., Rudmin 1983, 1991b, 1992c, 1993, 1994a, 1994b, 1999). Within these broad topic areas, "sharing" is an important aspect of owning, either as alternative forms of shared ownership juxtaposed to private ownership, or as a prerogative right that ownership allows. That is, sharing occurs because ownership is collective in one of many possible forms, or sharing occurs because private owners decide that they want to share their property.

That juxtaposition is the essence of the ancient political economics debate between Plato and Aristotle, both advocating consumer sharing: (1) Plato (1961, 1324) arguing in his Laws that the best society is one that enforces the proverb "friends' property is indeed common property" by ensuring that "all means have been taken to eliminate everything we mean by the word ownership," versus (2) Aris- totle $(1952,49)$ arguing in his Politics that in the best society, "each man will feel he is applying himself to what is his own" such that "moral goodness, and not as in Plato's scheme, legal compulsion, will ensure that the property of each is made to serve the use of all, in the spirit of the proverb which says, 'Friends' goods are goods in common."' This debate about sharing can be traced across two millennia (Rudmin 1988, 1991a), manifesting in our present era as the Cold War conflict between communism and capitalism. That is, sharing theory was recently debated by threats of nuclear bombs.

Sharing might best be defined as the simultaneous or sequential use of goods (e.g., cars, books, food, water), spaces (e.g., living rooms, gardens, decades, websites), or intangibles (e.g., experiences, beliefs, identities, heredity) by more than one individual. If there are multiple users of a resource, that is evidence that sharing is happening. The shared resources may be moveable material resources (e.g., tools, clothes, apples, slaves), or may be territorial resources (e.g., desk drawers, apartments, neighborhoods, countries), or may be immaterial resources (e.g., languages, designs, narratives, bitcoins).

Floyd Rudmin (floyd.rudmin@uit.no) is a professor, Psychology Department, UIT, Norway's Arctic University. The author thanks Russell Belk for his invitation to join this special issue, thanks Chris Caplice for his Edx.org course on "Supply Chain and Logistics Fundamentals," which inspired the idea that shopping is inventory behavior based on consumers' estimations of logistics parameters, and thanks Chris Neal for encouragement to take that course.

JACR, volume 1, number 2. Published online March 9, 2016. http://dx.doi.org/10.1086/685861

(c) 2016 the Association for Consumer Research. All rights reserved. 2378-1815/2016/0102-0006\$10.00 
Domains of sharing are contiguous with domains of owning, and domains of owning are always expanding as technologies develop that create new resources that have controlled access to use (Rudmin 1991b). For example, when architectural technology allowed adding upper stories to buildings, that commodified the space above an owned piece of land, and those aerial spaces can now be further commodified by dividing them into time units, now called "time-share vacation condos." Patents allow inventions to be owned, copyrights allow text to be owned, and trademarks allow words to be owned. New digital domains of ownership include online bank accounts, bitcoins, and virtual objects in virtual worlds (Robinson 2014).

Individual ownership and norms of exclusive use, to which sharing is juxtaposed, seem to be ubiquitous and seem to be the default norm, I here hypothesize (1) because the AngloSaxon societies dominate scholarly discourse and are also the global extremists in valuing individualism and private rights (Hofstede 2001), (2) because these same societies in the 60-year post-WWII era have enjoyed exceptional and well-distributed wealth that enables their populations to pursue exclusive individualistic use of property (Belk 2010), (3) because anticommunist ideologies during the Cold War deeply inculcated into the American mind a distaste for all forms of collective ownership, and (4) because scholarship arising from these cultural, economic, and ideological contexts may constrain theory by ignoring most modes of sharing. There is also the possibility (5) that the male voice of research reports diminished sharing because men tend not to be sharing, as observed by Pythagoras (Rud$\min$ 1990a, 1994b).

Thus, exclusive, private use of possessions appears in the literature as the normal, default mode of material relationships, such that "sharing" appears to be relatively rare or innovative, or perhaps revolutionary. I say "appears" because in reality, I will argue, sharing is ubiquitous in our contemporary Anglo-Saxon society and has been for centuries. Sharing resources has always been the norm, and exclusive use of resources has always been relatively rare. In my own life, unshared possessions include my eyeglasses, watch, toiletries, underwear, shoes, e-mail accounts, and some bank accounts. But my major possessions such as house, car, money, furniture, appliances, tools, computers, sports equipment, books, most clothes, and art are all shared, as are the atmosphere, roads, parks, and other public properties that I use. Future research might survey consumers to tabulate their shared and unshared goods and resources.
WHENCE COMES "THE SHARING ECONOMY"

Sharing is not new consumer behavior, nor is it a new topic of scholarship. A full-text search of the multidisciplinary literature in the JSTOR archive shows that the expression "sharing economy" first came into vogue in the 1980s following Weitzman's 1984 book The Sharing Economy: Conquering Stagflation, referring to economic arguments about profit sharing with workers (e.g., Dean 1986, 127; Blanchford and Oswald 1987, 3). In the 1990s, there was a different wave of interest in the "sharing economy," this time focused on anthropological studies of hunting-gathering cultures encountering modernity (e.g., Bird-David 1992; Rival 1997, 146; 1998, 621). Then a different use of the "sharing economy" followed from Lorna Gold's 2004 book The Sharing Economy: Solidarity Networks Transforming Globalization, focusing on moral and spiritual considerations of macroeconomic sharing in order to satisfy the needs of "distant strangers" (e.g., Daya and Authar 2012).

The phrase "sharing economy" first appeared in the New York Times in 2007 in the sentence, "The internet exploded a sharing economy with things like Wikipedia where people are doing work that creates a lot of value, not for the money, but just because it is their hobby" (Kummer 2007), or perhaps as their ensnarement and exploitation, as argued by Molesworth, Watkins, and Denegri-Knott (2016, in this issue). Since 2007, there have been dozens of appearances of "sharing economy" in the New York Times, including in Friedman's 2013 column "Welcome to the 'Sharing Economy." " Google has over 2 million hits for "sharing economy." Clearly, the concept and phrase have been well established in mainstream US culture.

The current focus on microeconomic sharing in the consumer behavior literature seems to have started with Belk's presentation in October 2006 at the University of Wisconsin conference on "The Politics of Consumption / The Consumption of Politics" (Shah et al. 2007). Belk's (2007) paper entitled, "Why Not Share Rather than Own?" was followed by his major review paper "Sharing" (2010), which provoked a research focus on "the sharing economy." The set of articles in this special issue arise from this recent research trend.

My method as a discussant was to read the first drafts of the manuscripts composing this special issue, and to allow them to excite the ideas I here develop. I will not be writing summaries or directed critical comments about each of the articles in this issue. Nor will I try to integrate them as some discussants do. These articles have helped me come to two critical contributions to research on sharing: (A) there needs 
to be more naive phenomenological observation and description of the contemporary consumer world; (B) there needs to be more consideration of research literature with historical depth and interdisciplinary breadth.

\section{NAIVE PHENOMENOLOGY OF SHARING TRANSPORTATION AND SHARING HOUSING}

"Phenomenology" is a much used and often misused concept. At one extreme, phenomenology entails orthodox methods of collecting subjects' self-report data, for example, by questionnaires, by interviews, or by diaries (e.g., Westbrook 1983; Fennel 1985; McQuarrie and McIntyre 1990). At another extreme, phenomenology entails often opaque analyses deriving from Husserl, Heidegger, and other abstractionists, requiring technical philosophical concepts such as bracketing, intentionality, Dasein, and so on (e.g., Churchill and Wertz 1985; Stewart 1987). The naive phenomenology advocated here does not require data from subjects, does not require philosophical technicalities, does not require introspective analysis of consciousness, and does not build on existing research literature. Rather, it is the method practiced by Gustav Ichheiser (1943, 1949), Fritz Heider (1958, 1983, 1987-89), and Irving Goffman (1956, 1971, 1979).

These scholars did influence one another. For example, Goffman's $(1956,2)$ first footnote in his first publication acknowledges Ichheiser's influence, and Ichheiser is one of the two most cited scholars in Heider's 1958 book The Psychology of Interpersonal Relations. Their method of naive phenomenology is to observe, especially what scholars have been overlooking, and to think about those observations, often using mental experiments or taxonomic structures (Rudmin et al. 1987; Rudmin 2010). Naive phenomenology is much like participant-observation of one's own activities, looking at them as though they were alien and thus seeing commonly unnoticed aspects of those activities.

Discussions of the new sharing economy often use the examples of car sharing via the digital platform of Uber and residence sharing via the digital platform of Airbnb. It thus seems appropriate to here demonstrate naive phenomenology by consideration of consumers' needs (1) to use a motor vehicle and (2) to use a vacation residence. I live in Ontario where it is very ordinary in the summer for a family to drive their car (owned or leased) to a cottage (owned, borrowed, or rented). The trip will start from a private driveway, take city streets, maybe use the provincial Route 401 across Toronto, maybe shift to the private toll road, Route 407, and the trip will invariably end using a cottage association's dirt road. In table 1 , I have listed many of the ways to have the use of motor vehicle transport, and many of the ways to have use of a road on which to operate a motor vehicle. In table 2 , I have listed many of the ways to

Table 1. Some Ways to Use a Motor Vehicle and Roadways

\begin{tabular}{ll}
\hline Ways to Use a Motor Vehicle & Ways to Use Roadways \\
\hline A. Use of vehicle only & A. Privately owned roadways \\
$\begin{array}{l}\text { 1. Individually owned car } \\
\text { 2. Leased car }\end{array}$ & $\begin{array}{l}\text { 1. Private driveway or roadway } \\
\text { 3. Rented car }\end{array}$ \\
$\begin{array}{ll}\text { 4. Car-share membership car } & \text { 3. Deeded right of way } \\
\text { 5. Family car } & \text { 4. Gated community roadway } \\
\text { 6. Company or employer's car } & \text { 5. Corporate driveway or parking lot } \\
\text { 7. Borrowed car, with permission } & \text { 6. Commercial toll road } \\
\text { 8. Borrowed car, without permission } & \text { B. Publicly owned roadways } \\
\text { 9. Stolen car } & \text { 7. Municipal roadway } \\
\text { B. Use of vehicle with a driver } & \text { 8. County roadway } \\
\text { 10. Taxi ride } & \text { 9. State roadway } \\
\text { 11. Uber ride } & \text { 10. National roadway } \\
\text { 12. Carpool ride } & \\
\text { 13. Hitchhike ride } & \\
\text { 14. Municipal bus ride } & \\
\text { 15. Commercial bus ride } & \end{array}$
\end{tabular}


Table 2. Some Ways to Use a Vacation Residence

\begin{tabular}{|c|c|}
\hline Ways to Use a Private Residence & Ways to Use a Commercial Residence \\
\hline 1. Privately owned cottage & 12. Hotel room rental \\
\hline 2. Family cottage & 13. Apartment rental \\
\hline 3. Rented cottage & 14. Bed and breakfast \\
\hline 4. Condominium cottage & 15. Public park cottage rental \\
\hline \multicolumn{2}{|l|}{ 5. Time-share cottage } \\
\hline \multicolumn{2}{|l|}{ 6. Cottage or trailer on leased lot } \\
\hline \multicolumn{2}{|l|}{ 7. Borrowed cottage, with permission } \\
\hline \multicolumn{2}{|l|}{ 8. House swap cottage } \\
\hline \multicolumn{2}{|l|}{ 9. Airbnb } \\
\hline \multicolumn{2}{|l|}{ 10. Couchsurfing } \\
\hline 11. Borrowed cottage, without permission & \\
\hline
\end{tabular}

have the use of a vacation residence. These listings come from my own naive observations of life around me. Readers might notice other options to add to these lists.

Consumer behavior research rarely, if ever, has observed that consumers use roadways. For example, Rose and Neidermeyer (1999) discussed competition on shared highways resulting in "road rage." Because all land on planet Earth is owned, then all roadways are owned and any theories of vehicle use must include consideration of roadway ownership and sharing. This observation can be generalized. Consumers are physical beings, located in physical space, as are the objects we use, like cars, Cokes, clothes, and cottages. Thus, consumer behavior might be considered to be a subfield of human geography because consumer goods and consumer activities are usually constrained by physical space and its ownership. The dream worlds of traditional societies and the virtual worlds of modern societies do require, respectively, functional brains or functioning computers, both of which exist in physical space. Commonly, consumers use and store their consumer goods in territories, buildings, rooms, and containers that demark ownership and secure those goods as property (Rudmin 1990b). Even homeless people have their shopping carts and temporarily privatized public spaces (Hill and Stamey 1990; Hill 1991).

Immaterial resources, such as ideas, beliefs, music, gods, dreams, names, nationalities, histories, and so on, are not located in physical space, but they may be defined in dimensional spaces that may be delimited, marked, secured by controlled access and thus owned (e.g., Chatwin 1998; Graham 2013). The possession and ownership of immaterial resources have a long history of discussion (e.g., Cooley 1902; Allport 1937; Litwinski 1942, 1947a, 1950, 1953;
Prelinger 1959; Altman 1970; Abelson 1986). Future research might review and elaborate these theories to incorporate shared possession and shared dispossession of immaterial resources, and to bring these theories up to date to include digitally defined immaterial resources.

Table 1 needs some explanation. First, notice that only the first two, " 1 . Individually owned car" and "1. Private driveway or roadway," can be used exclusively by an individual owner, that is, can be "not shared." All of the other options are unavoidably "shared," and these first two can also be shared if the owners wish. Thus, use of motor vehicles is primarily a shared consumer behavior, and it has been like that long before the sharing economy concept came into vogue. Second, notice that the only options in table 1 that contemporary scholarship on the sharing economy might bring focus on are "4. Car-share membership car" and "11. Uber ride." Those two options (a) are relatively new, (b) rely on digital communications (e.g., smart phones), and $(c)$ appeal primarily to a similar demographic who are relatively young, who are comfortable with digital communications, who have low or modest incomes, and who might have ecological or anticonsumerist attitudes (Bardhi and Eckhardt 2012). Future research might elaborate the similarities and differences between these new modes of car sharing and the long existing modes of car sharing.

Third, notice the two modes of unauthorized motor vehicle use, namely "8. Borrowed car, without permission" and "9. Stolen car." Neither of these was considered by Eckhardt and Bardhi (2016) in this issue. Most owners of the car would experience both of these as theft of the car. But these can be differentiated. In Mark Twain's novel Huckleberry Finn, Huck is impoverished but has need for watercraft to move about on the Mississippi River. He 
sometimes finds drifting, unowned canoes, rowboats, and rafts, but often he has to "borrow" secured boats without permission of the owners. He and his Pap reason that such "borrowing" is different from stealing: "it warn't no harm to borrow things if you was meaning to pay them back some time" (Clemens 1884, 45). Similarly, when I was studying the semantics of ownership in a Cree village on Hudson Bay, one elder said, "If someone takes that canoe out there, I wouldn't mind as long as they brought it back" (Rudmin 1994a, 126). This may reflect the finding that "need" is a stronger criterion of ownership rights in Cree language semantics than it is in English semantics (Rudmin 1994a). Gollnhofer, Hellwig, and Morhart (2016, in this issue) also found need to be a rightful claim to food in the context of German food sharing.

Fourth, notice that sequential sharing of a motor vehicle with other users at different times can be distinguished from simultaneous sharing with other users at the same time. For example, my family members sequentially share my car at different times during the day, but for any one trip, we can take other passengers and thus share the car simultaneously with other passengers. Future research might examine to what degree consumers differentiate sequential sharing from simultaneous sharing.

Fifth, notice the need to differentiate compensated sharing, usually as a monetary user fee as happens in car rentals, bus rides, taxi rides, or Uber rides, from uncompensated sharing, as happens in family sharing, hitchhiking, and carpooling. There may be further need to differentiate compensation to share operating costs compared to compensation to cover operating costs plus labor and profits. For example, in carpooling, riders may pay the driver a fair share of gas money, but with taxi rides and Uber rides, the payment covers fuel but also covers car purchase, licensing and insurance, maintenance, and the drivers' time. Future research might examine to what degree consumers conceive compensated sharing to be sharing, if at all.

Sixth, notice that juxtaposed with "private" ownership is "shared" ownership, and probably the most common form of shared ownership is public ownership. Some consumers, especially men, experience a sense of ownership over public property (Rudmin 1994b). All "public" property and consumer services, such as fire departments, water utilities, sewers, libraries, hospitals, schools, roads, parks, beaches, and so on, are shared by consumers because their ownership is shared via a government representing those consumers. In American history, Benjamin Franklin's reputation rests in part on his innovative promotion of a "sharing economy," although that label was not then used. For example, he demonstrated that private book ownership could be replaced by subscription libraries and public libraries, that private or sectarian hospitals could be replaced by public hospitals, that private guards and night watchmen could be replaced by municipal police, that commercial fire protection companies could be replaced by volunteer fire departments, and that sectarian religious universities could be replaced by public universities (Mumford 2002). Many Americans would cringe at the thought that Benjamin Franklin was a kind of communist. Future research might more fully document traditions and developments of consumer sharing in US history.

This discussion arising from observing different ways of motor transport sharing can be done for different ways of having use of a vacation residence, as listed in table 2 . Again, notice that only "Privately owned cottage" can be "not shared." But to my knowledge, most cottage owners share their cottages with family and friends. We humans are social beings and typically find pleasure in being with others. It may be that the very purpose of owning a cottage is to share it, much as Aristotle had theorized. Future research might survey cottage owners to measure their sharing motivations and their sharing behaviors.

All but one of the options in table 2 involve sequential and simultaneous sharing. Also, notice that the ownership of the dwelling can be separated from the ownership of the land on which the dwelling sits, as is common in trailer parks and campgrounds. The dwellings may be private, but the land may be shared via user fees, leases, or condominium contracts. In sum, a simple listing of alternative ways to have use of cars and cottages shows that consumer experience with cars and cottages is primarily as shared consumption. It is not a new development or revolution that we have a sharing economy in cars and cottages.

\section{NAIVE PHENOMENOLOGY OF THE FAMILY HOUSEHOLD SHARING}

If this analysis were generalized from cars and cottages to all consumer behavior, then observations of sharing might be sought in other domains. Consider the children in the family trip to the cottage. Children have ownership of very little, if anything. For the first two decades of our lives, most of us have no legal ownership of the objects, consumables, and spaces that we use. The family household is a form of a sharing economy between spouses but is exclusively so for their children. Belk (2010) considers sharing 
within the family to be the prototype for sharing. There is a paradox that we all learn our consumer behavior while being the beneficiaries of sharing in a household economy, but we come away believing that the norm of consumer behavior is exclusive use of privately owned resources.

This paradox might be explained by evidence that the family household displays nonlegal forms of ownership by which children learn the behaviors, attitudes, and emotions by which to become owners. Leon Litwinski is one of the most prolific scholars on the psychology of ownership (Rudmin 1990b, 1991c; Rudmin, Belk, and Furby 1987). He defined three different kinds of material relationships: occupancy, possession, and ownership (Litwinski 1913, 1942, 1947a, 1947b). Occupancy is the temporary and often coincidental having or use of a resource. Possession is the intentional conservation of a resource with expectation of future utility for the self. Ownership is possession that has been secured by social approbation or by the sanction of law. Ownership allows relaxed expectation. In this issue, Hill, Cunningham, and Gentleman (2016) document how the total institution of the prison permits only minimal possessions and those never with the surety of ownership, considering the arbitrariness of prison administration. Relaxed expectation is absent in prisons.

Possession and ownership demand cognitive and emotional effort, though this is much reduced by ownership norms when other people and the juridical state confirm and protect an owner's possessions. In 1942, Litwinski noted that the then consumer revolution of disposable goods reduced the mental demands of ownership:

Possession creates cares, burdens, risks. The Americans who lead the way in material progress try to simplify the existence of civilized man by ridding him of certain of the anxieties of the possessor. In seeking a new formula for this, one no longer gives oneself the trouble of sending handkerchiefs to the laundry: they are immediately replaced. It is more economical and at the same time simpler. It is a notable example of progress. Not to possess too much will one day be the criterion of progress, of independence and of liberty. (Litwinski 1942, 31)

Future research might examine the correlations between participation in "the sharing economy" and consumers' motivations to reduce the mental demands of maintaining an inventory of consumer goods or motivations to engage forms of voluntary simplicity (Rudmin and Kilbourne 1996).
To better understand Litwinski's differentiation of occupancy, possession, and ownership, consider the illustrative example of a child finding a stick in the park and playing with it. If this is a coincidental and brief activity, that is occupation of the stick. If the child modifies it, expects to play with it tomorrow, hides it in a bush, and maybe worries about it at night, that is possession of the stick. If other children and the adults all acknowledge that it is his or her stick and will defend the child's possession, that is ownership of the stick. The child will then not have to hide the stick or worry about it. If others ask permission to use the stick, that is evidence they acknowledge ownership. The owner has the recognized right to share the stick, or not. If a friend says, "Now it is my turn to have the stick," that is a declaration that the stick is shared property, not private property, and the new co-owner is asserting an owner's right to use.

Future research might examine how children learn occupancy, possession, and ownership as well as norms of sharing, in the ordinary routines of the household. For example, family meals usually have "owned" seating, with everyone having their routine and rightful place. In some families, or for some special meals, food is ritually distributed by the head of household, who thereby enacts ownership of the food and the owner's right to share it (Wallendorf and Arnould 1991). Food that is distributed from a serving dish to a child's dinner plate becomes the private property of the child. Others may not take it without permission, and the child may modify it to his or her liking. Furthermore, the child may leave the table with expectation that the food will still be there when he or she returns, if the absence is not too long. Litwinski (1942, 32) explained that ownership "is often rewarded by a feeling of detachment equivalent to indifference," which can become excessive, resulting in "the destruction of possessiveness, in consequence of its indifference."

In most households, children "own" their toys and their storage areas, perhaps their private bedrooms. "Own" here means that others in the family respect possessive attachment to these and seek permission before having shared use. Many sibling quarrels revolve around perceptions of violated ownership, and parents must sometimes adjudicate these disputes (e.g., Hay and Ross 1982; Ross 1990; Hay 2006). In my own upbringing, in a family of six children, our mother enforced a rule of property abandonment: any toys, books, or other possessions that she picked up while cleaning would be placed in "the bin," and those possessions, abandoned through indifference, could be claimed 
and kept by anyone, including neighboring kids, rummaging in the bin. Thus, sophisticated property theory was not articulated to the children, but we nevertheless learned something of Litwinski's theory that ownership allows relaxed possession but that excessive relaxation becomes in difference, which becomes dispossession.

There is a large research literature on the development of ownership and sharing among toddlers, preschoolers, and young children. This seems to have begun around 1960 with seminal studies by Handlon and Gross (1959), Fischer (1963), and Doland and Adelberg (1967). PsychINFO indexes 171 studies from 1950 to 2015 found by searching < (toddlers OR preschooler* OR kindergarten OR nursery OR daycare) AND sharing $>$ in the title, abstract, or key-concepts fields. Several of the most recent studies are provocative. For example, Chernyak and Kushnir (2013) demonstrated that children share more from their own resources if they have prior experience of choice about sharing. Ulber, Hamann, and Tomasell (2015) demonstrated that toddlers share resources by ownership cues and by principles of equity, much as Gollnhofer et al. (2016, in this issue) discovered for food sharing in Germany. Liu et al. (2016) demonstrated that sharing by Chinese children increases as age progresses from 3 to 11 , and that greater inhibitory self-control predicts greater sharing.

Furthermore, studies of children's development of "altruism" and "prosocial behavior" often operationalize these concepts with measures of sharing. For example, $\mathrm{Ma}$ and Chan (2014) measured high school students' altruism by their readiness to share knowledge, and Ibbotson (2014) presented a meta-analysis of 14 studies that used sharing as the measure of prosocial behavior in children. Berndt (1981) discovered that boys shared less with friends than with acquaintances, possibly because they are competitive with their friends. Considering that all adult sharing behavior will arise through developmental processes, it seems important that scholarship on consumer sharing include deep and current reviews of the child developmental literature.

\section{POSSESSIONS AS INVENTORY; SHARING AS SUPPLY CHAIN DEMAND}

Litwinski's theory of property also leads to a line of speculation: if possessions are inventory for future use by the possessor, then consumers' acquisitions of possessions by shopping are forms of inventory management. Consumer goods can be possessed by shoplifting (Cox, Cox, and Moschis 1990), but purchasing them will bestow well-recognized ownership (Rudmin and Berry 1987; Rudmin 1994a, 1994b), which ensures that the inventory is secure. Furthermore, if sharing is one of the uses that property can be put to, then expectations of sharing may enter into the shopping decision processes.

Inventory and supply chain management is an applied science discipline, with a rich taxonomy, well-developed theories, a wide research literature, and advanced computational methods, all of it far too extensive to elaborate here. However, even basic, introductory texts describe the core concepts and processes by which businesses acquire and maintain inventory (see Silver, Pyke, and Peterson 1998; Ballou 2003; Cachon and Terwiesch 2011; Chopra and Meindl 2012). If expressed in the vocabulary of the household consumer, and if "cost" includes not just money but human costs of damaged expectations, lost opportunities, ugly emotions, and so on, then the central processes of consumer supply chain management are (1) forecasting how much will be consumed, or how frequently an object will be used, and in what time period, (2) estimating the error in the forecast, (3) finding optimal balance between household storage costs and shopping costs in order to estimate the optimal amount to purchase, (4) finding optimal balance between storage costs and the aggravation costs of not having something available when it is wanted, (5) deciding what is the acceptable risk of not having something available when it is wanted, giving consideration to errors in forecasting, and (6) deciding with what frequency to do the shopping.

It is here hypothesized that ordinary consumers engage such processes, without the overtly articulated reasoning or computational considerations employed in businesses. Consumers may unconsciously, or in their heuristics and habits, be imagining their use frequency of consumer goods, estimating the various costs, calculating the trade-offs, and establishing decision policies about risks of shortages. For example, people with backgrounds of poverty and scarcity, or those with morbid fears of not being good parents, or good partners, or good hosts, may appear irrational in their excessive shopping and purchasing, but may merely be misforecasting demand or misestimating variability in their demand forecast, or may have a policy of low risk of stocking out. Their inventory behaviors may be rational given their estimates and policies. Consumers and businesses do sometimes shop in the same settings, buying the same types and quantities of goods, for example in Costco and in Staples, so it is not unreasonable that they might employ similar purchase and inventory decision processes. With institutions like Airbnb and Uber, consumers are using their personal consumer resources as business resources. Thus, 
the distinctions between consumer inventory and business inventory can break down.

This hypothesis that consumers act like supply chain managers might be tested by surveying graduate students in supply chain management courses, asking for examples of their personal consumer habits being similar to formalized business practices. Another approach would be to employ experimental advertising, to determine whether inducing consumers to think of supply chain parameters can influence their purchase decisions. For example, an experimental ad might promote the small storage space of a product, thereby inducing consumers to estimate lower holding costs, which should increase the purchase quantity and decrease the shopping frequency. Future research might also develop psychometric scales and subscales of consumer inventory style.

This line of thought has several possibilities of explanatory force on the topic of sharing. First, it is possible that sharing is being forecast by consumers, as elevated demand forecast, or as greater error in demand forecast, or as a cost of stocking out if sharing cannot be done. For example, in my household of two adults, we have five snow shovels, in part, because neighbors sometimes want to borrow a snow shovel, and we want to be able to lend. The holding cost of extra snow shovels is minimal since we have a garage with storage area for winter stuff up in the rafters. But the cost of not having a snow shovel to lend is to be unneighborly. In this case, forecasting the need for snow shovels has large error because severity of snow storms is unpredictable, neighbors are changing, and neighbors' personal snow shovel purchasing policies are unknown. Such forecasting error requires surplus snow shovels, if we are to have minimal risk of running out of snow shovels. However, as we approach old age and dependency on our adult children, then the cost of household inventory increases in the form of anticipated nuisance for our adult children to get rid of our inventory. That cost will eventually weigh against our inventory of five shovels.

In a field research study, Wallendorf, Belk, and Heisley (1988) encountered a man who had two double garages, both full of assorted consumer inventory because, he explained, if someone needed something, he wanted to have it to lend to them. That is, his forecast error included not knowing what items might be needed to be shared, and his risk level of not having inventory was low; hence, he maintained excessive inventory despite the holding costs of having to forego garage parking space for his vehicles.

The supply chain management theory of consumer behavior, however, might have greatest utility in explaining the new forms of digitally mediated sharing. Consider cars. Purchasing and maintaining a car in an urban setting has monetary costs but also cognitive and stress costs. There are irregularly scheduled activities that must not be missed, such as license renewals, insurance payments, maintenance services, and so on, all of which impose cognitive demands. There are anxiety costs of worry about collisions, break-ins, thefts, parking tickets, and so on. There are social costs of friends and relatives wanting to have rides or to borrow the car, and being angry if denied. In supply chain theory, these are all "holding costs," costs of keeping the inventory of an owned car, although Sun, Supangkat, and Balasubramanian (2016, in this issue) consider these to be "inconvenience costs." If such costs are high, that weighs toward low inventory, which in this case means low access to a car ride; in other words, not owning a personal car. If a person's forecast demand of car use is relatively low, or if the speed of access to a car-share vehicle or to an Uber ride approaches that of an owned car, or if the consumer can accept a higher risk of "stock outs" precluding immediate access to a car ride, then it is rational in supply chain theory to not keep the inventory of an owned car. It is access to car transport that is consumed; an owned car is merely the inventory object that allows such access (Bardhi and Eckhardt 2012; Eckhardt and Bardhi 2016). This ignores ego investment in automobiles for some people, although this could perhaps also be subsumed within inventory theory. Habibi, Kim, and Laroche (2016, in this issue) describe the risk of "stock outs" as "scarcity risk." Future research might study car-share members and Uber users to see if any supply chain parameters enter their decisions to forgo car ownership. Future research might also use inventory theory to explain why Bill Gates, Warren Buffet, and George Soros do not participate in the sharing economy as Uber drivers or Uber customers, or as Airbnb hosts or guests.

\section{SHARING AS COMPETITION}

Often unnoticed in the literature on sharing is that more than one user of an object or a space causes there to be competition between users. For simultaneous sharing, within the physical world, this is often a zero-sum competition. That is, if I am in the shower, my siblings cannot be in the shower, and if I have the preferred seat in the car, my siblings cannot have the preferred seat in the car. In American slang, to "call dibs" is a claim in a zero-sum sharing context to have priority use, or temporary ownership, of the coveted space or position. To call dibs means that the caller 
was the first one to notice an impending zero-sum competition for a shared resource and has staked his or her priority claim to the asset. That claim is usually recognized by the competitors. Calling dibs denies the possibility of simultaneous sharing and declares that sharing will be sequential. A dibs-owned asset can be gifted, traded, or sold, at least in my childhood household. Rules of right-of-way similarly manage competition among drivers for the shared space of the roadway. Raising hands in a classroom similarly manages competition for shared speaking space. Future research might examine competition phenomena and methods of managing competition in other consumer contexts of sharing.

Sharing of immaterial resources does not naturally have competition because immaterial resources are not confined by physical space. There is no limit to the number of people sharing a language, a belief, an experience, and so on. Usage by one person does not naturally preclude usage by another person. However, such competition can be artificially or legally imposed. For example, copyright and trademark laws restrict usage of owned texts and of owned words. Sharing of digital resources also does not naturally admit of competition. For example, usage of digital music and videos by one person does not impede usage of the same music and videos by others. It is indeed possible that the current interest in consumer sharing is driven in part by the greater role and easier access that digital resources now have in the routines of our lives. Future research might more extensively describe the phenomenology of sharing of immaterial resources and theorize about relationships among users and between owners and users that such resources impose.

Just as there are extensive research literatures on ownership theory, on child development, and on inventory management, so too are there several domains of research literatures on competition in contexts of sharing that should be reviewed and useful aspects of theory introduced to consumer behavior research. One domain is set within biology, focused on species, or individuals within species, competing for shared resources of food, territory, mates, and so on. A full-text search of JSTOR's biological journals, using the search expression $<$ (sharing OR shared) AND competition $>$ found 26,000 articles, and the same search in Google Scholar found 11,000 articles. For example, Jaeggi and Schaik (2011) studied food sharing among primates and concluded that it facilitates coalition building. Gurven (2004) examined reciprocal altruism in food sharing among hunter-gatherers. It might be noted that Baker and Baker (2016, in this issue) reported that shared narratives of sharing material resources in a storm-damaged community were a major component in restoring the coalition of the community.

Another domain of research on competition in contexts of sharing pertains to economic theories of equilibrium that optimize allocation of shared resources between competitors. This topic was popularized to some degree by the depiction of John Nash in the film A Beautiful Mind. A fulltext search of JSTOR using the search expression $<$ (shared or sharing) and competition and "Nash equilibrium" $>$ found 2,000 articles, and the same search in Google Scholar found 24,000 articles. For example, Madani (2010) demonstrated that game theory can identify system-wide optimal allocation of shared water resources. Similarly, Wei et al. (2010) argued that game theory can identify optimal allocation of cloud computing resources.

Another domain of research on competition in contexts of sharing pertains to the unregulated competition for shared resources leading to destroying those resources. The seminal presentation of this was Hardin's (1968) article on the "Tragedy of the Commons." A full-text search of JSTOR using the search expression $<$ (shared or sharing) and competition and "tragedy of the commons" $>$ found 2,000 articles, and the same search in Google Scholar found 21,000 articles. For example, Mergesal (1996) argued that the privatization of science, in the form of patents and intellectual property rights, is destroying what is essentially a collective project of shared knowledge. Brown and Vincent (2008) used economic game theory to demonstrate that the tragedy of the commons can be impeded by decelerating benefits or accelerating costs.

There probably are other domains of scholarship that consider competition in contexts of sharing. Future studies of consumer sharing might include reviews of such literatures in order to identify useful theories, models, and paradigms in order to bring more focus on aspects of competition that might be expected to appear in the sharing economy.

\section{CONCLUSION}

The "sharing economy" is going to be an enduring and everevolving aspect of consumer life. Digital communications make distributed consumer inventory available on short notice, and decreasing affluence means that more and more people will be unable to maintain private ownership of consumer inventory. Scholarship on the sharing economy will need to develop taxonomies, concepts, theories, models, and 
research paradigms by which to understand and explain sharing.

\section{REFERENCES}

Abelson, Robert P. (1986), "Beliefs Are Like Possessions," Journal for the Theorv of Social Behavior, 16 (3), 223-50.

Allport, Gordon W. (1937), Personality: A Psychological Interpretation, New York: Holt.

Altman, Irwin (1970), "Territorial Behavior in Humans: An Analysis of the Concept," in Spatial Behavior in Older People, ed. L. A. Pastalan and D. A. Carson, Ann Arbor, MI: University of Michigan Press, 1-24.

Aristotle (1952), The Politics of Aristotle, trans. Ernest Barker, London: Oxford University Press.

Baker, Stacey M., and Courtney N. Baker (2016), "The 'Bounce' in Our Steps: From Shared Material Resources in Cultural Trauma and Recovery," Journal of the Association for Consumer Research, 1 (2), in this issue.

Ballou, Ronald H. (2003), Business Logistics: Supply Chain Management, 3rd ed., Upper Saddle River, NJ: Pearson Prentice Hall.

Bardhi, Fleura, and Giana M. Eckhardt (2012), "Access-Based Consumption: The Case of Car Sharing," Journal of Consumer Research, 39 (4), $1-18$.

Belk, Russell W. (2007), “Why Not Share Rather than Own?" Annals of the American Academv of Political and Social Science, 611 (1), 126-40. - (2010), "Sharing," Journal of Consumer Research, 36 (5), 715-34.

Berndt, Thomas J. (1981), "Effects of Friendship on Prosocial Intentions and Behavior," Child Development, 52 (2), 636-43.

Bird-David, Nurit (1992), "Beyond 'The Original Affluent Society': A Culturalist Reformulation," Current Anthropology, 33 (1), 25-47.

Blanchford, David G., and Andrew J. Oswald (1987), "Profit Sharing —Can It Work?" Oxford Economic Papers, n.s., 39 (1), 1-19.

Brown, Joel S., and Thomas L. Vincent (2008), "Evolution of Cooperation with Shared Costs and Benefits," Proceedings: Biological Sciences, 275 (1646), 1985-94.

Cachon, Gerard, and Christian Terwiesch (2011), Matching Supply with Demand: An Introduction to Operations Management, 3rd ed., New York: McGraw-Hill.

Chatwin, Bruce (1998), The Songlines, New York: Random House.

Chernyak, Nadia, and Tamar Kushnir (2013), "Giving Preschoolers Choice Increases Sharing Behavior," Psychological Science, 24 (10), 1971-79.

Chopra, Sunil, and Peter Meindl (2012), Supply Chain Management, Strategy, Planning, and Operation, 5th ed., Upper Saddle River, NJ: Pearson Prentice Hall.

Churchill, Scott D., and Frederick J. Wertz (1985), "An Introduction to Phenomenological Psychology for Consumer Research: Historical, Conceptual, and Methodological Foundations," Advances in Consumer Research, 12 (1), 1-7.

Clemens, Samuel L. (1884), The Adventures of Huckleberry Finn, New York: Harper \& Brothers.

Cooley, Charles H. (1902), Human Nature and the Social Order, New York: Scribner's.

Cox, Dina, Anthony D. Cox, and George P. Moschis (1990), "When Consumer Behavior Goes Bad: An Investigation of Adolescent Shoplifting," Journal of Consumer Research, 17 (2), 149-59.

Daya, Shari, and Raksha Authar (2012), "Self, Others and Objects in an 'Alternative Economy': Personal Narratives from the Heiveld Rooibos Cooperative," Geoforum, 43 (5), 885-93.

Dean, Robert H. (1986), "Macroeconomic Conflicts and Economic and Social Policies," Review of Social Economv, 44 (2), 113-29.
Doland, Dilman J., and Kathryn Adelberg (1967), "The Learning of Sharing Behavior," Child Development, 38 (3), 695-700.

Eckhardt, Giana, and Fleura Bardhi (2016), "The Relationship between Access Practices and Economic System," Journal of the Association for Consumer Research, 1 (2), in this issue.

Fennel, Geraldine (1985), "Things of Heaven and Earth: Phenomenology, Marketing, and Consumer Research," Advances in Consumer Research, 12 (1), 544-49.

Fischer, William F. (1963), "Sharing in Preschool Children as a Function of Amount and Type of Reinforcement," Genetic Psychology Monographs, 68, 219-45.

Friedman, Thomas L. (2013), "Welcome to the "Sharing Economy," New York Times, July 20, http://www.nytimes.com/2013/07/21/opinion /sunday/friedman-welcome-to-the-sharing-economy.html.

Goffman, Erving (1956), The Presentation of Self in Everyday Life, Edinburgh: University of Edinburgh Social Sciences Research Centre. - (1971), Relations in Public: Microstudies of the Public Order, New York: Basic.

(1979), Gender Advertisements, New York: Harper \& Row.

Gold, Lorna (2004), The Sharing Economy: Solidarity Networks Transforming Globalization, London: Ashgate Economic Geography Series.

Gollnhofer, Johanna F., Katharina Hellwig, and Felicitas Morhart (2016), "Fair Is Good but What Is Fair? Negotiations of Distributive Justice in an Emerging Non-monetary Sharing Model," Journal of the Association for Consumer Research, 1 (2), in this issue.

Graham, Mark (2013), "Geography/Internet: Ethereal Alternate Dimensions of Cyberspace or Grounded Augmented Realities?" Geographical Journal, 179 (2), 177-82.

Gurven, Michael (2004), "Reciprocal Altruism and Food Sharing Sessions among Hiwi and Ache Hunter-Gatherers," Behavioral Ecology and Sociobiologv, 56 (4), 366-80.

Habibi, Mohammad H., Andrea Kim, and Michel Laroche (2016), "From Sharing to Exchange: An Extended Framework of Dual Modes of Collaborative Non-ownership Consumption," Journal of the Association for Consumer Research, 1 (2), in this issue.

Handlon, Britomar J., and Patricia Gross (1959), "The Development of Sharing Behavior," Journal of Abnormal and Social Psychology, 59 (3), 425-28.

Hardin, Garrett (1968), "The Tragedy of the Commons," Science, 162 (3859), 1243-48.

Hay, Dale (2006), “Yours and Mine: Toddlers' Talk about Possessions with Familiar Peers," British Journal of Developmental Psychology, 24 (1), 3952.

Hay, Dale, and Hildy Ross (1982), "The Social Nature of Early Conflict," Child Development, 53 (1), 105-13.

Heider, Fritz (1958), The Psychology of Interpersonal Relations, Hillsdale, NJ: Erlbaum.

(1983), Das Leben eines Psychologen: Eine Autobiographie [The life of a psychologist: An autobiography], Bern: Verlag Hans Huber.

- (1987-89), The Notebooks, ed. M. Benesh-Weiner, MünchenWeinheim: Psychologie Verlags Union.

Hill, Ronald P. (1991), "Homeless Women, Special Possessions, and the Meaning of 'Home': An Ethnographic Case Study," Journal of Consumer Research, 18 (3), 298-310.

Hill, Ronald P., Daniel Cunningham, and The Gramercy Gentlemen (2016), "Dehumanization and Restriction inside a Maximum Security Prison: Novel Insights about Consumer Acquisition and Ownership," Journal of the Association for Consumer Research, 1 (2), in this issue. 
Hill, Ronald P., and Mark Stamey (1990), "The Homeless in America: An Examination of Possessions and Consumption Behaviors," Journal of Consumer Research, 17 (3), 303-21.

Hofstede, Geert (2001), Culture's Consequences: Comparing Values, Behaviors, Institutions, and Organizations across Nations, 2nd ed., Thousand Oaks, CA: Sage.

Ibbotson, Paul (2014), "Little Dictators: A Developmental Meta-Analysis of Prosocial Behavior," Current Anthropology, 55 (6), 814-21.

Ichheiser, Gustav (1943), "Why Psychologists Tend to Overlook Certain 'Obvious' Facts," Philosophy of Science, 10, 204-7.

- (1949), "Misunderstandings in Human Relations: A Study of False Social Perception," American Journal of Sociology, 550 (2), 1-69.

Jaeggi, Adrian V., and Carel P. Van Schaik (2011), "The Evolution of Food Sharing in Primate," Behavioral Ecology and Sociobiology, 65, 2125-40.

Kummer, Luke J. (2007), "A Boston Newspaper Prints What the Local Bloggers Write," New York Times, May 7, http://www.nytimes.com /2007/05/07/business/media/07boston.html\&pagewanted=all?_r=0.

Litwinski, Leon (1913), “Qu'est-ce que la propriété?” [What is property?], Revue internacionale de sociologie, 21, 427-52.

- (1942), "Is There an Instinct of Possession?" British Journal of Psychology, 33 (1), 28-39.

_ (1947a), “The Psychology of 'Mine,'” Philosophy, 22 (83), 240-51.

- (1947b), "Une nouvelle théorie psychologique du lien possessoire: L'attente dans la détente" [A new psychological theory of possessive attachment: Relaxed expectation], Journal de psychologie normale et pathologique, 40, 432-54

- (1950), Psychopathologie de l'intolerance et de fanatism [Psychopathology of intolerance and fanaticism], Paris: UNESCO.

- (1953), "Être et avoir" [To be and to have], in Proceedings of the XIth International Congress of Philosophy, Bruxelles, August 20-26, 1953, vol. 7, Amsterdam: North-Holland, 162-68.

Liu, Buyun, Zhelan Huang, Guifeng Xu, Yu Jin, Yajun Chen, Xiuhong Li, Qingxiong Wang, Shanshan Song, and Jin Jing (2016), "Altruistic Sharing Behavior in Children: Role of Theory of Mind and Inhibitory Control," Journal of Experimental Child Psychology, 141 (January), $222-28$.

Ma, Will W. K., and Albert Chan (2014), "Knowledge Sharing and Social Media: Altruism, Perceived Online Attachment Motivation, and Perceived Online Relationship Commitment," Computers in Human Behavior, 39 (C), 51-58.

Madani, Kaveh (2010), "Game Theory and Water Resources," Journal of Hvdrology, 381 (3), 225-38.

McQuarrie, Edward F., and Shelby H. McIntyre (1990), "What the Group Interview Can Contribute to Research on Consumer Phenomenology," in Research in Consumer Behavior, vol. 4, ed. Elizabeth C. Hirschman, Greenwich, CT: JAI Press, 165-94.

Mergesal, Robert P. (1996), "Property Rights Theory and the Commons: The Case of Scientific Research," Social Philosophy and Policy, 13, $145-67$.

Molesworth, Mike, Rebecca Watkins, and Janice Denegri-Knott (2016), "Possession Work on Hosted Digital Consumption Objects as Consumer Ensnarement," Journal of the Association for Consumer Research, 1 (2), in this issue.

Mumford, Michael D. (2002), "Social Innovation: Ten Cases from Benjamin Franklin," Creativity Research Journal, 13 (2), 253-66.

Plato (1961), Laws V, in The Collected Works of Plato, ed. E. Hamilton and H. Cairns, Princeton, NJ: Princeton University Press, 1314-31.

Prelinger, Ernst (1959), "Extension and Structure of the Self," Journal of Psvchologv, 47, 13-23.
Rival, Laura (1997), "Modernity and the Politics of Identity in an Amazonian Society," Bulletin of Latin American Research, 16, 137-51.

(1998), "Parents and Guest Children: The Huaorani Couvade," Journal of the Royal Anthropological Institute, 4 (4), 619-42.

Robinson, Edward H. (2014), "The Aspatial Economics of Virtual Worlds," Journal of Virtual Worlds Research, 7 (1), 1-21.

Rose, Randal L., and Mandy Neidermeyer (1999), "From Rudeness to Road Rage: The Antecedents and Consequences of Consumer Aggression," Advances in Consumer Research, 26 (1), 12-17.

Ross, Hildy S. (1990), "Negotiating Principles of Entitlement in Sibling Property Disputes," Developmental Psychologv, 32 (1), 90-101.

Rudmin, Floyd W. (1983), "Semantics of Ownership: A Study Based on Free-Recall and on Explicit Judgements," unpublished MA thesis, Queen's University, Kingston, Ontario.

(1985), "Historical Note on the Development of Possessive Pronouns," Journal of Speech and Hearing Disorders, 50 (3), 298-99.

(1986), "Psychology of Ownership, Possession and Property: A Selected Bibliography since 1890," Psvchological Reports, 58 (3), 85967.

(1988), "Dominance, Social Control and Ownership: A History and a Cross-Cultural Study of Motivations for Private Property," Behavior Science Research, 22 (1-4), 130-60.

(1990a), "German and Canadian Data on Motivations for Ownership: Was Pythagoras Right?" in Advances in Consumer Research, vol. 17, ed. M. E. Goldberg, G. Gorn, and R. W. Pollay, Provo, UT: Association for Consumer Research, 176-81.

(1990b), "The Economic Psychology of Leon Litwinski (18871969): A Program of Cognitive Research on Possession and Property," Journal of Economic Psychology, 11 (3), 307-39.

(1991a), "Having: A Brief History of Metaphor and Meaning," in "Law and Economics and the Semiotic Process," ed. R. P. Malloy, special issue, Syracuse Law Review, 42, 163-79.

(1991b), "Ownership as Agency, and the Crystallization of Property," chap. 15 in Action and Agency, ed. R. Kevelson, New York: Peter Lang, 263-76.

_ (1991c), “'To Own Is to Be Perceived to Own': A Social Cognitive Look at the Ownership of Property," Journal of Social Behavior and Personality, 6 (6), 85-104.

(1992a), "Cross-Cultural Correlates of the Ownership of Private Property," Social Science Research, 21 (1), 57-83.

- (1992b), "Cross-Cultural Correlates of the Ownership of Private Property: A Look from Another Data Base," Anthropologica, 34 (1), $71-88$.

(1992c), "Frege's Semiotics Sampled: The Sense and Reference of the Verb 'Own," chap. 18 in Law and the Human Sciences, ed. R. Kevelson Rudmin, New York: Peter Lang, 357-73.

(1993), "Dispossession for Semiotic Distance: The Objective Facts of Ownership in the Eye of White Fang," chap. 21 in Flux, Complexity, and Illusion: Semiotics and the Human Sciences, vol. 6, ed. R. Kevelson, New York: Peter Lang, 391-406.

(1994a), "Cross-Cultural Psycholinguistic Field Research: Verbs of Ownership and Possession," Journal of Cross-Cultural Psvchology, 25 (1), 114-32.

- (1994b), "Gender Differences in the Semantics of Ownership: A Quantitative Phenomenological Survey Study," Journal of Economic Psychology, 15 (3), 487-510.

(1995), "Cross-Cultural Correlates of the Ownership of Private Property: Two Studies of Murdock's Data," Journal of Socio-Economics, 24 (2), 345-73. 
(1996), "Cross-Cultural Correlates of the Ownership of Private Property: Zelman's Gender Data Revisited," Cross-Cultural Research 30 (2), 115-53.

- (1999), "Property," in The Philosophy of Law: An Encyclopaedia, ed. C. B. Gray, New York: Garland, 695-97.

(2010), "Phenomenology of Acculturation: Retrospective Reports from the Philippines, Japan, Quebec and Norway," Culture and Psychologv, 16 (3), 313-32.

Rudmin, Floyd W., Russell W. Belk, and Lita Furby (1987), Social Science Bibliography on Property, Ownership and Possession: 1580 Citations from Psychology, Anthropology, Sociology, and Related Disciplines, Monticello, IL: Vance.

Rudmin, Floyd W., and John W. Berry (1987), "Semantics of Ownership: A Free-Recall Study of Property," Psychological Record, 37 (2), 25768.

Rudmin, Floyd W., and William E. Kilbourne (1996), "The Meaning and Morality of Voluntary Simplicity: History and Hypotheses on Deliberately Denied Materialism," in Consumption and Marketing: Macro Dimensions, ed. R. W. Belk, N. Dholakia, and A. Venkatesh, Cincinnati, OH: South-Western College Publishers, 166-215.

Rudmin, Floyd W., Rudiger Trimpop, Ilona-Patricia Kry, and Pawel Boski (1987), "Gustav Ichheiser in the History of Social Psychology: An Early Phenomenology of Social Attribution," British Journal of Social Psychologv, 26 (2), 165-80.

Shah, Dhavan V., Douglas M. McLeod, Lewis Friedland, and Michelle R. Nelson (2007), "Introduction: The Politics of Consumption / The Con- sumption of Politics," Annals of the American Academv of Political and Social Science, 611, 6-15.

Silver, Edward A., David F. Pyke, and Rein Peterson (1998), Inventory Management and Production Planning and Scheduling, 3rd ed., New York: Wiley.

Stewart, Roderick M. (1987), "Intentionality and the Semantics of 'Dasein,'” Philosophv and Phenomenological Research, 48 (1), 93-106.

Sun, Jiong, Hendrarto Supangkat, and Siva Balasubramanian (2016), "Peer-To-Peer Sharing of Private Goods: Sellers' Response and Consumers' Benefits," Journal of the Association for Consumer Research, 1 (2), in this issue.

Ulber, Julia, Katharina Hamann, and Michael Tomasell (2015), "How 18and 24-Month-Old Peers Divide Resources among Themselves," Journal of Experimental Child Psychology, 140 (August), 228-44.

Wallendorf, Melanie, and Eric J. Arnould (1991), "'We Gather Together': Consumption Rituals of Thanksgiving Day," Journal of Consumer Research, 18 (1), 13-31.

Wallendorf, Melanie, Russell W. Belk, and Deborah Heisley (1988), "Deep Meaning in Possessions: The Paper," Advances in Consumer Research, 15 (1), 528-30.

Wei, Guiyi, Athanasios V. Vasilakos, Yao Zheng, and Naixue Xiong (2010), "A Game-Theoretic Method of Fair Resource Allocation for Cloud Computing Services," Journal of Supercomputing, 54 (2), 252-69.

Westbrook, Robert A. (1983), "Consumer Satisfaction and the Phenomenology of Emotions during Automobile Ownership Experiences," in International Fare in Consumer Satisfaction and Complaining Behavior, ed. R. L. Day and H. K. Hunt, Bloomington: Indiana University, 2-9. 